(c) CEDA/TU, 2015, US Library of Congress, Catalog Card No. : 79-915209, ISSN: 2091-0339

The Journal of Development and Administrative Studies (JODAS), Vol. 23(1-2), pp. 23-32

\title{
Study of Nepal's Economic Relations with China
}

- Uma Shankar Prasad*

\begin{abstract}
Nepal has a very long historical, political, cultural and economic cooperation with China. According to the International Monetary Fund (IMF), China is the country having the world's largest economy in 2014 for purchasing power parity with 17.632 trillion US dollar and second largest economy for nominal GDP. Being one of the rising Asian powers, China wants to achieve the status of global power. In this perspective, it is needed for China to win the trust of neighbouring countries. China has already announced that it will pay more attention and reinforce its cooperation with its neighbours. Being a China's good neighbour, Nepal naturally wants to see China as a global power in coming years. This article analyzes some facets of Nepal's long economic relation with China. The paper concludes that although the political and economic relation between Nepal and China has very long history, the relation has not been able to enhance various economic indicators like trade, investment, tourism etc. and therefore it is needed to focus on economic endeavours between these two countries in coming days.
\end{abstract}

Keywords: Purchasing power parity (ppp), global power, freetrade, bilateral agreement and remittances

JEL Classifications: $\mathrm{F}_{10}, \mathrm{~F}_{15}, \mathrm{G}_{28}$ and $\mathrm{H}_{50}$

\section{Introduction}

Nepal is a land-locked country situated between two emerging and fast-growing economiesIndia and China. Nepal shares $1,415 \mathrm{Km}$. border with China in the north. Nepal and China have a long history of political and economic relations. The first recorded official relations between Nepal and China dated from the middle of the seventh century, although unofficial contracts between these two countries began in the fifth century. Some of the most prominent figures who immortalized Nepal-China relations are Fa-hsien, Hsuan-tsang, Wang Hsuan-Tse, Buddhabhadra and Arniko (Manandhar, 1999).

Nepal's sending quinquennial missions to China after the Nepal-Tibet-China war of 1792 continued up to 1906. Nepal successfully sent altogether thirteen quinquennial missions to

\footnotetext{
* Dr. Prasad is Associate Professor at Central Department of Economics, Tribhuvan University, Kirtipur, Nepal, Corresponding Email: umashankarceda@gmail.com
} 
China for the first sixty years 1792 - 1852. After the Nepal-Tibet War of 1855-56, the system of sending Nepalese missions to China became quite irregular. For during the fifty-four years period (1852 - 1906), Nepal dispatched only five missions to China (Manandhar, 1999).

The first agreement between China and Nepal on economic aid was signed in October 1956. Nepal and China have established Inter-governmental Economic and Trade Committee (IGETC) in October 1982. The IGETC meetings have become the main forum for discussion on Nepal-China bilateral economic and technical cooperation.

In 2005, Nepal and China celebrated the $50^{\text {th }}$ anniversary of the establishment of diplomatic relations between Nepal and China. In 2009, the state leaders of Nepal and China agreed to establish "China-Nepal Comprehensive Cooperative Partnership" to bring the bilateral relations to a new height. Since then, high-level visits between the two countries have become more frequent. At the beginning of 2012, Premier Wen Jiabao successfully visited Nepal.

Chinese foreign minister Wang Yi visited Nepal from 25 - 27 December 2014. On the occasion, Nepal and China agreed to enhance cooperation in nine vital areas: trade, investment, agriculture, infrastructure, science and technology, connectivity, cultural exchanges, tourism and security law enforcement. Wang announced a grant assistance of RMB 800 million (approximately NPR 13 billion) to Nepal for next fiscal year which is four-fold increase in China's assistance to Nepal from last year. Nepal Rastra Bank and People's Bank of China have agreed to proceed commercial activities between China and Nepal in RMB.

Two neighbours are celebrating diamond jubilee of diplomatic relations next year in 2015 after 60 years. On the occasion of diamond jubilee, it is expected to visit the Chinese President Xi Jinping to Nepal.

China has even taken the initiative to aid Nepal in its economic and social development. China provides grants for various infrastructure development and other projects undertaken in Nepal. The Nepal-China Chamber of Commerce and Industry (NCCCI), since its foundation in 1999, has been striving to stimulate trade and boost economic relations between two countries.

\section{China's Position in the World}

China is a socialist country. It has the world's fast-growing economy with growth rates averaging 10 per cent over the past 30 years. It has the world's biggest merchandise traders in 2013 with imports and exports totalling US\$ 4,159 billion. China's share of global trade has increased from 3 per cent at the start of the year 2000 to 10 per cent in 2013. It has recorded a trade surplus of US\$259 billion, 2.8 per cent of its GDP (WTO, 2014). China has the world's second largest economy in terms of FDI inflows with US\$ 124 billion and it is the world's third largest country in terms of FDI outflows with US\$ 101 billion in 2013 (UNCTAD, 2014). 
However, its position in terms of per capita GDP and HDI is far below than the developed countries of the world.

China is well positioned as the sole representative from Asia and from the developing world among the permanent members of the United Nations Security Council. It participates actively in international groupings like the G-20 and BRICS. Beijing has developed international collaboration in the variety of Asian regional groupings that have emerged in the past two decades. Prominent international dignitaries have called upon the United States and China to take the leading role in global politics by forming a G-2 alignment to deal with salient international problems (Sutter, 2010).

China has accumulated massive foreign exchange reserves reaching over US\$ 4 trillion by the end of 2014. This has come about in part because of large Chinese trade surpluses in recent years along with large capital inflows into China for investment. In 2014, China remained a top recipient of foreign direct investment.

China is bordered by 14 countries that range from small nations such as Bhutan to very large ones like Russia and India. Most of the Chinese neighbours are either with low or medium GNI and HDI as shown in Table 1 below:

Table 1: Selected indicators of China's neighbouring countries

\begin{tabular}{|c|c|c|c|c|c|c|c|c|}
\hline \multirow{2}{*}{ Country } & \multirow{2}{*}{$\begin{array}{l}\text { Population } \\
\text { millions } \\
2012\end{array}$} & \multirow{2}{*}{$\begin{array}{l}\text { Surface area } \\
\text { thousand Sq. } \\
\text { Km. } 2012\end{array}$} & \multicolumn{2}{|c|}{$\begin{array}{l}\text { Gross national income } \\
\text { Atlas method }\end{array}$} & \multicolumn{2}{|c|}{$\begin{array}{c}\text { Purchasing power } \\
\text { parity }\end{array}$} & \multicolumn{2}{|c|}{ HDI } \\
\hline & & & $\begin{array}{l}\text { \$ billion } \\
2012\end{array}$ & $\begin{array}{l}\text { Per capita } \\
\$ 2012\end{array}$ & $\begin{array}{l}\text { \$ billion } \\
2012\end{array}$ & $\begin{array}{l}\text { Per capita } \\
\$ 2012\end{array}$ & Value & Rank \\
\hline Russia & 143.5 & $17,098.2$ & $1,822.7$ & 12,700 & $3,272.9$ & 22,800 & 0.778 & High \\
\hline India & $1,236.7$ & $3,287.3$ & $1,913.2$ & 1,550 & $4,730.3$ & 3,820 & 0.586 & Medium \\
\hline Kazakhstan & 16.8 & $2,724.9$ & 164.3 & 9,780 & 179.9 & 11,790 & 0.757 & High \\
\hline Mongolia & 2.8 & $1,564.1$ & 8.8 & 3,160 & 14.0 & 5,020 & 0.698 & Medium \\
\hline Pakistan & 179.2 & 796.1 & 225.1 & 1,260 & 516.5 & 2,880 & 0.537 & Low \\
\hline Myanmar & 52.8 & 676.6 & $\mathrm{NA}$ & NA & NA & $\mathrm{NA}$ & 0.524 & Low \\
\hline Afghanistan & 29.8 & 652.2 & 20.4 & 680 & 46.6 & 1,560 & 0.468 & Low \\
\hline Vietnam & 88.8 & 331.0 & 137.5 & 1,550 & 321.4 & 3,620 & 0.638 & Medium \\
\hline Laos & 6.6 & 236.8 & 8.4 & 1,270 & 17.9 & 2,690 & 0.569 & Medium \\
\hline Kyrgyzstan & 5.6 & 199.9 & 5.5 & 990 & 12.4 & 2,220 & 0.628 & Medium \\
\hline Nepal & 27.5 & 147.2 & 19.2 & 700 & 40.4 & 1,470 & 0.540 & Low \\
\hline Tajikistan & 8.0 & 142.6 & 7.1 & 880 & 17.4 & 2,180 & 0.607 & Medium \\
\hline North Korea & 24.8 & 120.5 & NA & NA & NA & NA & NA & NA \\
\hline Bhutan & 0.7 & 38.4 & 1.8 & 2,420 & 4.6 & 6,200 & 0.584 & Medium \\
\hline
\end{tabular}

Source: World Development Indicators 2014, The World Bank Human Development Report 2014, United Nations Development Programme 
With the exception of North Korea and Myanmar, China's aid to Asia is very small especially in comparison to other donors. Therefore, it is necessary for China to increase the aid to its neighbouring countries in order to get support from these countries in future.

From time immemorial, Nepal and China have been close neighbours sharing common border. They have strong political, economic, social and cultural relations. These centuries old traditional relations were formalized with the establishment of diplomatic ties between the two countries in 1 August 1955. Nepal has established Consulate General's Offices in Hong Kong and Lhasa and an honorary consul has been appointed in Shanghai.

Nepal-China relations are based on the five principles (Panchsheel): a) respect to each other's sovereignty and territorial integrity b) non-aggression c) non-interference in each others' internal affairs economically, politically and ideologically d) equality and mutual benefit e) peaceful co-existence. Nepal and China are supporting each other in many regional and international forums, including the United Nations.

The Nepal-China boundary is as old as the history of the two countries. Many believe that the demarcation of Nepal-China boundary had been a problem in the past, mainly because more than 90 percent of the frontiers run through high altitudes with rocks and snow. The few territorial disputes that existed over rival claims for the settlements of Kimathanka in the Sankhuwasahba and Taplejung districts, the area adjoining the boarder of Rasuwa, and Nara Nangla of Humla district with the origin of dispute dating back to 1815, 1818 and 1843 respectively. However, these disputes and the whole demarcation of Nepal-China boundaries were resolved by the Nepal-China Joint Boundary Commission on 5 October 1961 (Sapkota 2013).

The flow of Tibetan into Nepal started when the $14^{\text {th }}$ Dalai Lama left Lhasa for India in 1959. There are about 20,500 Tibetan refugees living in 12 settlements across the country in Nepal. However, the true number of Tibetan refugees is unknown. Some estimates show that 30,000 Tibetans live in Kathmandu alone. There are several protests from Tibetan activities that have taken place in Nepal within last couple of years.

Nepal started to initiate a strict boarder-control policy in 1989. On 30 April 2010, the Department of Immigration (DoI) sent nine Tibetans to jail after they refused to pay fines for illegal entrance to Nepal. Nepal has assured Beijing's one China policy which declares that both Taiwan and Tibet are inalienable parts of Chinese territory.

\section{Nepal's Economic Relation with China}

Economic cooperation is one of the most important dimensions of Nepal-China bilateral relations. Nepal and China economic relation was established in ancient times as a local trade between Tibet and Kathmandu. The first attempt to enhance the economic cooperation between 
Nepal and China was legally made only after the signing of agreement on trade between two countries on 20 September 1956. The establishment of the Inter-Governmental Economic and Trade Committee (IGETC) in October 1982 was the next step to increase the trade between two countries. The IGETC meetings have become the main forum for discussions on NepalChina bilateral economic and technical cooperation. Nepal-China economic cooperation can be broadly analysed under four categories: trade, grant aid, investment and tourism.

Trade: Nepal's trade is highly dominated by India. Nepal's trade with Tibet in 1959/60 was only 0.98 percent of total trade (Pant, 1962) which increased to 7.9 percent in 2001/02 and further increased to 10.3 percent in 2010/11 (Table 1).

Table 2: Direction of Nepal's total trade, 2001/02 and 2010/11

\begin{tabular}{|c|l|r|r|r|r|}
\hline \multirow{2}{*}{ S. N. } & \multirow{2}{*}{ Country } & \multicolumn{2}{|c|}{$\mathbf{2 0 0 1 / 0 2}$} & \multicolumn{2}{|c|}{$\mathbf{2 0 1 0 / 1 1}$} \\
\cline { 3 - 6 } & & Value in '000 Rs. & $\begin{array}{c}\text { Share in } \\
\mathbf{\%}\end{array}$ & Value in '000 Rs. & Share in \% \\
\hline 1. & India & $84,578,300$ & 54.2 & $302,030,385$ & 65.4 \\
\hline 2. & China P.R. & $12,307,072$ & 7.9 & $47,555,232$ & 10.3 \\
\hline 3. & Others & $59,136,217$ & 37.9 & $112,512,769$ & 24.3 \\
\hline & Total & $\mathbf{1 5 6 , 0 2 1 , 5 8 9}$ & $\mathbf{1 0 0 . 0}$ & $\mathbf{4 6 2 , 0 9 8 , 3 8 6}$ & $\mathbf{1 0 0 . 0}$ \\
\hline
\end{tabular}

Source: Trade Statistics, Trade and Export Promotion Centre, Government of Nepal, 2013

Although Nepal's trade with China is in increasing trend, it is far below than potential. Due to less developed transport system, the trade between two countries could not flourish. There is also the absence of dry port in Nepal for Nepal-China bilateral trade. As many believe that Nepal could play as a transit point not only between India and China but with whole South Asian countries, it is necessary to interlink the region with road and railway network which will enhance the trade between Nepal and China in future.

The volume of Nepal-China trade is growing and so is the remarkably wide trade imbalance. This needs to be corrected to make our bilateral trade sustainable in the long run. In November 2012, China and Nepal signed the letter of exchanges allowing 7,787 Nepalese products exported to China free of tariff. Duty free access of Nepalese products to the markets in China could help to decrease the trade deficit of Nepal.

Grant aid: The Government of Peoples Republic of China has been providing assistance to the Government of Nepal under the bilateral Agreement of Economic and Technical Cooperative signed between two countries.

China has always been a steady and reliable partner in Nepal's development endeavour, more specifically in the areas of infrastructure and human resources development, education, health and food assistance, among others. 
Table 3: Chinese aid in Nepal, 2010/11 and 2011/12

\begin{tabular}{|c|r|r|r|r|}
\hline \multirow{2}{*}{ Year } & \multirow{2}{*}{ Total aid (US\$) } & \multicolumn{3}{|c|}{ Chinese aid } \\
\cline { 3 - 5 } & & US\$ & \% & Growth rate \\
\hline $2010 / 11$ & $1,079,710,554$ & $18,843,988$ & 1.7 & - \\
\hline $2011 / 12$ & $1,045,297,273$ & $28,344,923$ & 2.7 & 50.4 \\
\hline
\end{tabular}

Source: Development Cooperation Report Fiscal Year 2011/12, Ministry of Finance, Government of Nepal, 2013

Over the past 50 years, with China's financial and technical assistance, more than 30 projects have been completed in Nepal. As recognized by people of all circles in Nepal, these projects have played a constructive role in the social and economic development of Nepal. The Arniko Highway, the Ring Road, Prithivi Highway, Kathmandu-Bhaktpur road, Gorkha-Narayanghat road, Sunkoshi Hydro Project, the Birendra International Convention Centre, Hetauda Cotton Mill, Bansbari Leather and Shoe Factory, Bhaktpur Brick and Tile Factory, Bhrikuti Paper Mill, Lumbini Sugar Mill, Gorakkali Rubber Udhyog etc are some examples of such projects assisted by Chinese government.

Investment: China is top most investor in Nepal and Chinese investment in Nepal is growing although it is presently lower in comparison to the need and potential. Greater Chinese involvement particularly in the fields of water resources and infrastructure building would be extremely helpful potentially leading to a win-win outcome. By July 2013, 575 projects under Chinese investment have been approved in Nepal with investment of NPR 10,632 million which helped to create 31,594 jobs (Figure 1 and 2).

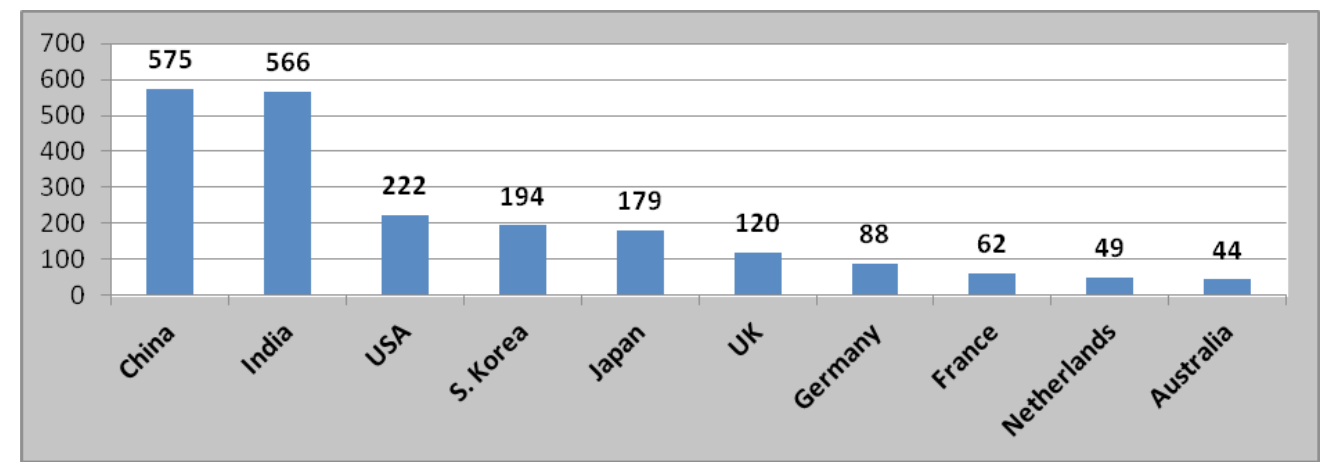

Figure 1: Top 10 countries approved for industrial foreign investment in Nepal up to fiscal year 2012/13

Source: Industrial Statistics Fiscal Year 2012/13, Department of Industry, Government of Nepal, 2013

Nepal Trade Integration Strategy (NTIS) 2010 has identified 19 export potential goods and services. They are: cardamom, ginger, honey, lentils, tea, instant noodles, medicinal herbs and essential oils, handmade paper and paper products, silver jewellery, iron and steel products, 
chyangra pashmina products, wool products, tourism, labour services, IT and BPO services, health services, education services, engineering services and hydro-electricity (MoCS, 2010).

It is needed for Nepal to focus its short to medium-term efforts to increase these products in Nepal for exports. China could invest in these potential products to get benefit based on the principle of win-win situation. China's investment in these export potential goods and services of Nepal would be a great support to decrease Nepal's trade deficit.

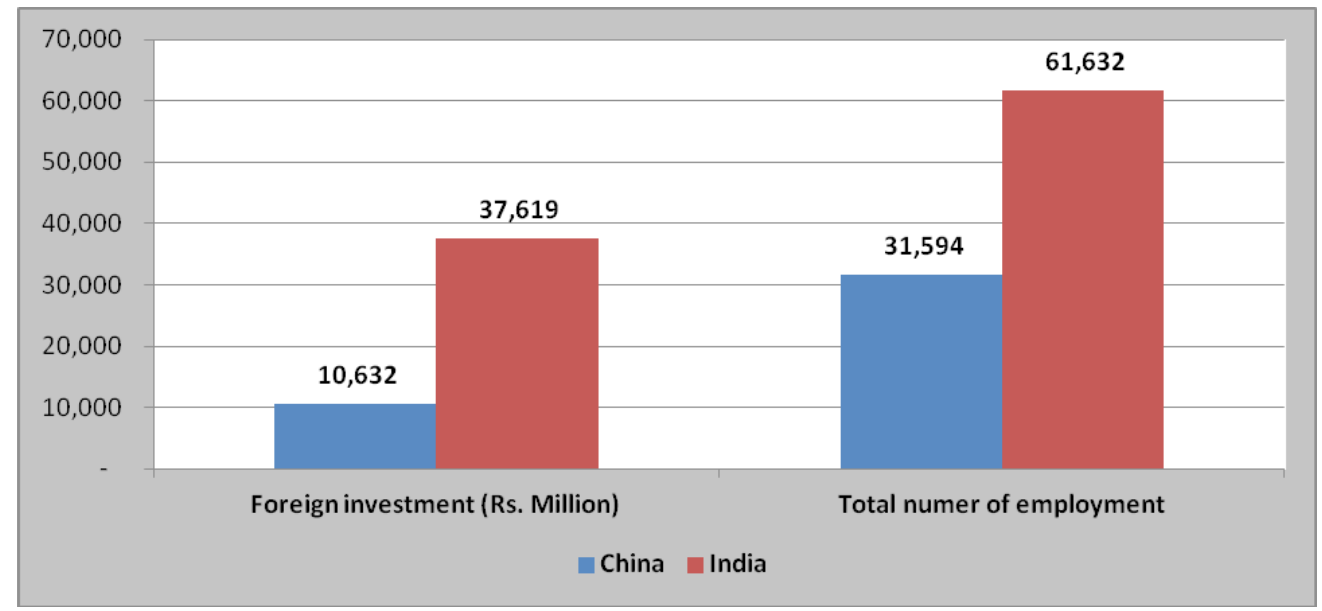

Figure 2: Foreign investment and total number of employment generated by approved industries by China and India in Nepal up to fiscal year 2012/13

Source: Industrial Statistics Fiscal Year 2012/13, Department of Industry, Government of Nepal, 2013

Labour migration and remittances comprise a crucial component of income for many less fortunate and less-endowed Nepalese people who perform their work at a place distant from their house. Most of the workers are sent to the Gulf countries where risk is very high and working environment is dangerous. People going to abroad for foreign employment from Nepal have increased sharply in recent years. Most of the youth labour force is attracted towards foreign employment as a result of inability to create employment opportunities in the domestic labour market and increased temptation of youths in foreign employment.

Every day about 1,500 youths are estimated going abroad from Nepal for foreign employment. As a result of unavailability of employment opportunities in the domestic employment market seventy four percent of the total foreign bound youths are unskilled while 25 percent are semiskilled and 1 percent is skilled (MoF, 2014).

A total of 109 countries are opened for foreign employment by 2014 (MoF, 2014). India has been a most important destination for Nepalese workers due to its physical proximity 
and labour markets in India are comparatively easily accessible. The number of migrants to India for work are generally estimated about 1 million to 3 million based on different studies. Household heads especially illiterate household heads are more likely to migrate to India.

However, migration, in recent years, has increased dramatically with the opening up of newer markets for Nepali labour in the Republic of Korea, Malaysia, Qatar, Saudi Arabia and other Middle Eastern countries. Various reports claim that there are about 1,000,000 Nepali migrant workers working in various international foreign labour markets except India. Chinese investment in Nepal will certainly create many job opportunities in domestic market in Nepal.

Tourism: Nepal is uniquely endowed with rich and diverse natural resources and cultural attractions. There is not any other country in the world which has such an incomparable cultural heritage as well as such a rich environmental spectrum from the highest mountains to the Terai plains. Tourism is, therefore, a sector of comparative advantage which can be instrumental in spreading the benefits and providing alternative economic opportunities to build peace and prosperity for the people of Nepal. Tourism can contribute to poverty reduction through economic, social, environmental and cultural benefits. It provides diversified employment opportunities, which provides additional income. Tourism also increases government revenue which can be used to alleviate poverty through more investment for education, health and infrastructure development.

Nepal and China have signed an agreement on Cultural Exchange in 1964 which was revised again in December 1999 to include tourism as one of the components. Nepal has made Chinese Yuan convertible for tourists and businessmen. The following Table shows the tourist arrival in Nepal from China from 2001 to 1012:

Table 4: Chinese tourist arrival in Nepal, $2001-2012$

\begin{tabular}{|c|r|r|r|r|}
\hline \multirow{2}{*}{ Year } & Total number of & \multicolumn{3}{|c|}{ Chinese tourists } \\
\cline { 3 - 5 } & tourists & Number & \% & Growth rate \\
\hline 2001 & 361,237 & 8,738 & 2.4 & -0.3 \\
\hline 2002 & 275,468 & 8,715 & 3.2 & -13.2 \\
\hline 2003 & 338,132 & 7,562 & 2.2 & 76.2 \\
\hline 2004 & 385,297 & 13,326 & 3.5 & 67.9 \\
\hline 2005 & 375,398 & 22,377 & 6.0 & -21.6 \\
\hline 2006 & 383,926 & 17,538 & 4.6 & 63.2 \\
\hline 2007 & 526,705 & 28,618 & 5.4 & 22.9 \\
\hline 2008 & 500,277 & 35,166 & 7.0 & -8.2 \\
\hline 2009 & 509,956 & 32,272 & 6.3 & 43.7 \\
\hline 2010 & 602,867 & 46,360 & 7.7 & 33.6 \\
\hline 2011 & 736,215 & 61,917 & 8.4 & 16.1 \\
\hline 2012 & 803,092 & 71,861 & 8.9 & . \\
\hline
\end{tabular}

Source: Nepal Tourism Statistics 2012, Ministry of Culture, Tourism and Civil Aviation, Government of Nepal, 2013 
These existing agreements between Nepal and China on cultural exchanges and tourism, the Araniko Highway, and air connections from different cities of China to Kathmandu have contributed towards increasing the number of Chinese tourists coming to Nepal. Likewise, China has become an emerging tourism market for tourists coming to Nepal. In order to further promote bilateral tourism, there should be expansion of direct flights and increase in the frequency of flights between the two capitals. Cooperation between tourist authorities and travel agencies of both countries needs to be further promoted. China can promote its citizens to visit Nepal which will be helpful for Nepal to increase its foreign currency reserves.

\section{Future Prospects}

The future prospects of Nepal-China economic relations can be viewed from different perspectives as explained below:

Transportation network: There is only one road link between Nepal and China through Arniko Highway. Recently an agreement has been signed to interlink both countries linking Kerong of Tibet through Rasuwa in Nepal by railway.

There is an urgent need to develop transport system between two countries and construct a dry port in Nepal in order to enhance the bilateral trade between Nepal and China. Nepal is regarded as transit point between China and India as well as among all South Asian countries. There is the need of road, railway and air connectivity among these countries. It is needed to develop air connectivity between Kathmandu and Beijing.

Study and research: There has been lack of study, research, debate and discussions on Nepal-China political and economic relations. More interactions among think tanks between Nepal and China are required. Establishment of research centres in both countries is necessary. Political as well as intellectual tours need to be increased.

Trade and investment: Nepal has already signed the Bilateral Investment Promotion and Protection Agreement (BIPPA) with India. BIPPA is also necessary between Nepal and China to increase the Chinese investment in Nepal. Chinese investment is necessary to focus on marginalized regions of Nepal like Madhesh, Karnali and far-west region.

Grant aid for Nepal's marginalized regions: Madhesh, Karnali and far-west regions are politically and economically marginalized regions of Nepal. Per capita government expenditure in these regions has been far below than other parts of the country. HDI value is also low in these regions. Therefore, it is necessary to provide grants aid for these regions from the Government of China.

\section{Concluding Remarks}

There has been multidimensional and friendly relationship between Nepal and China for time immemorial irrespective of changes of government in Nepal. Nepal-China cooperation is based on the principle of Panchsheel. Mutual relationship has been increasing in several sectors like political, economic, cultural, tourism, educational etc. China has been extending sympathy, 
support and assistance. Nepal is also supporting one China policy and not allowing any antiChinese activities in Nepalese soil. Nepal respects China's sovereignty and territorial integrity with respect to Tibet and Taiwan. In this way, the scope of mutual relationship between Nepal and China are becoming broader and broader but it needs to enhance further in coming days.

\section{References}

DoI (2013). Industrial Statistics Fiscal Year 2012/13. Department of Industry, Government of Nepal.

FCGO (2008). Consolidated Financial Statements: Fiscal Year 2006/07, Kathmandu: Financial Comptroller General Office, Government of Nepal.

Manandhar, Vijay Kumar (1999). Cultural and Political Aspects of Nepal-China Relations. Delhi: Adroit Publishers.

MoCTCA (2013). Nepal Tourism Statistics 2012, Ministry of Culture, Tourism and Civil Aviation, Government of Nepal.

MoF (2013). Development Cooperation Report Fiscal Year 2011/12. Ministry of Finance, Government of Nepal.

Pant, Y. P. (1962). Nepal-China Trade Relations: The Economic and Political Weekly (http://www.epw.in/system/files/pdf/1962_14/15/nepalchina_trade_relations.pdf).

Sapkota, Rupak (2013). Prospects of Nepal-China-India Trilateral Cooperation: A Perspective from Nepal, Unpublished Masters' Thesis, Shandong University.

Shrestha, HiranyaLal (2005). Political Aspect of Nepal-China Relations. in Nishchal N. Pandey (ed.) Nepal-China Relations. Kathmandu: Institute of Foreign Affairs.

TEPC (2013). Nepal Overseas Trade Statistics 2012/13. Kathmandu: Trade and Export Promotion Centre, Ministry of Industry, Commerce, and Supplies, Government of Nepal.

Thapa, Hira Bahadur (2005). Economic Dimension of Nepal-China Relations. in Nishchal N. Pandey (ed.) Nepal-China Relations. Kathmandu: Institute of Foreign Affairs.

UNCTAD (2014). World Investment Report 2014, New York and Geneva: United Nations Conference in Trade and Development.

UNDP (2014). Human Development Report 2014. New York: United Nations Development Programme.

WB (2014). World Development Indicators. Washington D. C.: The World Bank.

WTO (2014). International Trade Statistics 2014. Geneva: World Trade Organization.

MoCS (2010). Nepal Trade Integration Strategy 2010: Executive Summary and Action Matrix. Kathmandu, Ministry of Commerce and Supplies, Government of Nepal.

MoF (2014). Economic Survey 2013/14. Kathmandu: Ministry of Finance, Government of Nepal.

Note: Views and opinions expressed in this article are the personal views of author. 